\title{
Habitat use of a multispecific seagrass meadow by green turtles Chelonia mydas at Mayotte Island
}

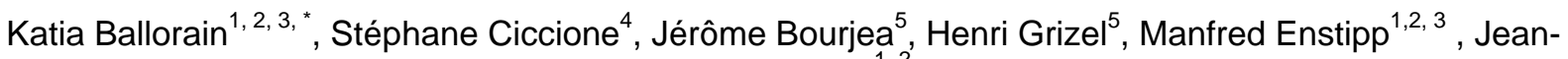 \\ Yves Georges ${ }^{1,2}$ \\ 1 Université de Strasbourg, IPHC, 23 rue Becquerel 67087 Strasbourg, France \\ 2 CNRS, UMR7178, 67037 Strasbourg, France \\ ${ }^{3}$ Ecole Doctorale Interdisciplinaire, Université de La Réunion, 15 Avenue René Cassin, BP 7151, 97715 Saint- \\ Denis Messag Cedex 9. \\ ${ }^{4}$ KELONIA, l'Observatoire des tortues marines de La Réunion, 48 Rue du Général de Gaulle, 97898 Saint Leu \\ Cedex, La Réunion, France. \\ ${ }^{5}$ Institut Français de Recherche pour l'Exploitation de la Mer de La Réunion, Rue Jean Bertho, BP 60, 97822 Le \\ Port Cedex, La Réunion, France.
}

\section{*: Corresponding author : Katia Ballorain, email address : katia.ballorain@c-strasbourg.fr, Phone/ Fax number:} +33388106900/+33388106906

\begin{abstract}
:
We investigated the habitat use in green turtles exploiting a 13-ha multispecific seagrass meadow at Mayotte Island, south-western Indian Ocean. A phyto-ecological survey shows the occurrence of eight seagrass species, dominated by Halodule uninervis and Syringodium isoetifolium, distributed according to four distinct seagrass communities along the depth gradient. Direct underwater censuses show that green turtles occurred all over the meadow. Yet when community relative surface area was taken into account green turtles preferentially frequented the most seaward, biomass-richer $S$. isoetifolium-dominated community, suggesting that green turtles compensate for their intrinsically nutrient-poor herbivorous diet. Additionally, smaller $(<80 \mathrm{~cm}$ standard curved carapace length, SCCL) individuals also preferentially occurred in the most shoreward $H$. univervis-dominated community where no larger (>80 $\mathrm{cm} \mathrm{SCCL}$ ) individuals were sighted, suggesting habitat use is indicative of diet selection and may reflect size-specific food requirements and physiology.
\end{abstract}




\section{Introduction}

Living organisms are thought to behave optimally while facing trade-offs between the energetic costs and benefits of survival, growth, and reproduction (Stephens and Krebs 1986; Krebs and Davies 1997). The rules governing foraging strategies are commonly predicted by Optimal Foraging Theory (MacArthur and Pianka 1966), which assumes that organisms optimize their feeding activities by maximizing energy intake, while limiting foraging costs. This process is mainly expressed by the way organisms exploit their feeding habitat in space and time, while coping with abiotic and biotic constraints (Cézilly and Benhamou 1996). For example, mammals, birds, and reptiles have been shown to adjust their foraging behaviour and time-budget in relation to ambient temperature, prey availability, predation, and intraspecific competition (e.g. Georges et al. 2000; León and Bjorndal 2002; Pinaud et al. 2005; Fossette et al. 2008; Blanchard et al. 2008).

Foraging strategies are also driven by individual metabolic requirements which depend on age, size, physiological and reproductive status. In vertebrates, young individuals of a given species have been shown to compensate for the greater physiological demands associated with growth by selecting different habitats and diets than adults (Benavides et al. 1994; Mobley and Fleeger 1999 for fish; Durtsche 2004; Bouchard and Bjorndal 2006 for reptiles; Herpol 1967 for birds; Pellew 1984 for mammals). Similarly, reproductive costs may differ between males and females and cause inter-sexual segregation in terms of habitat use, foraging behaviour and diet (see Mobley and Fleeger 1999 for fish; Barclay 1991; Ruckstuhl 1998; Le Boeuf et al. 2000; Wolf et al. 2005 for mammals).

Among consumers, herbivores and carnivores differ in that they consume food that varies greatly in nutritional and energetic values (Mattson 1980; Stephens and Krebs 1986; White 1993). Herbivores commonly compensate for the low nutritional and energetic quality of their food by increasing foraging time and being specialist feeders (Krebs and Davies 1997). To date, most studies concerning herbivores have focused on terrestrial ecosystems and show that plant-herbivore interactions mainly depend on the spatio-temporal heterogeneity of plant distribution, availability and quality (Wallis de Vries 1996; Drescher et al. 2006). In most terrestrial systems this leads to extended migrations of herbivores (Frank et al.1998) and to food selection according to plant energy and nutritional content (van Wieren 1996; Krebs and Davies 1997), palatability (including chemical and physical properties; Baumont 1996; Vourc'h et al. 2002), and toxicity (Bergvall and Lemar 2005).

Herbivory has been less extensively investigated in aquatic ecosystems and this is particularly true for low latitudes. In marine ecosystems, plants are represented by a high number of plankton and algal species, and a limited number of seagrass species. Yet, seagrass meadows significantly contribute to marine primary production and biomass (Duarte and Chiscano 1999). Seagrass meadows also play a key role in marine ecosystems by serving as refuges for the juvenile stages of many animal species and also providing a foraging habitat for numerous invertebrate and vertebrate species (Nagelkerken et al. 2000). In addition, seagrass meadows occur in shallow coastal waters and are therefore relatively easy to access and monitor in comparison to most other marine ecosystems. Their distribution and dynamics are predominantly affected by light levels (Peralta et al. 2002), temperature (McMillan 1984), water turbidity (Newell and Koch 2004), nutrient attenuation (Short 1987), substrate (Bandeira 2002a), and grazing pressure from herbivores (Jupp et al. 1996). Among herbivores, larger species such as manatees Trichechus sp., dugongs Dugong sp., and green turtles Chelonia mydas contribute significantly to the consumption of tropical seagrass biomass (Aragones 1996). The green turtle is the only sea turtle species that feeds on seagrass and algae (Bjorndal 1997) and it is therefore of great importance to investigate the trophic ecology of this species, which is of conservation concern in its natural environment

To date, most studies investigating the feeding ecology of green turtles have focused on juvenile individuals feeding on monospecific seagrass meadows and multispecific algal patches. These studies report that green turtles use various foraging strategies, which 
depend on the trophic conditions and the inter-specific interactions. On monospecific seagrass meadows of Thalassia testudinum, green turtles have been reported to continuously re-crop the same seagrass plots (Zieman et al. 1984; Moran and Bjorndal 2007): such re-cropping results in persistent patches of young, epiphytic free algae, nitrogen rich, and easily digestible leaves that can be exploited continuously over 16 months. In multispecific algae assemblages, green turtles reportedly either fed in proportion to the relative abundance of algal species (e.g. López-Mendilaharsu et al. 2008) or targeted only selected species (e.g. Coyne 1994; Forbes 1996). Finally, in areas where seagrass and algae co-exist, immature green turtles have been reported to select the most digestible, yet least abundant species (Brand-Gardner et al. 1999). In addition to trophic considerations, it has been suggested that green turtles should adjust their habitat use and food selection in relation to water temperature, interspecific competition with other large herbivores and threat of predation. Green turtles have been reported to avoid waters where temperature potentially becomes too warm $\left(>36^{\circ} \mathrm{C}\right)$, to prevent over fermentation of ingested food (Hasbùn et al. 2000). Considering inter-specific interactions with other large herbivores, such as dugongs that exclusively feed on seagrass, green turtles have been shown to select a mixed diet of algae and seagrass (André et al. 2005). Green turtles can also modify their spatiotemporal pattern of grazing to avoid predators such as sharks and make a trade-off between nutritious profitability and predation risk (Heithaus et al.

2007).

To date, few studies have investigated the ecology of green turtles within multispecific seagrass meadows. Furthermore, they have rarely focused on adult individuals and did not consider the determinants driving their distribution and behaviour (Coyne 1994). Here, we investigate the habitat use of a population of green turtles when feeding on a multispecific seagrass meadow, at Mayotte Island, Southwestern Indian Ocean (SWIO). The SWIO hosts some highly productive, biodiversity rich, multispecific seagrass meadows (Wakibya 1995; Bandeira 2002b; Güllström 2002). At Mayotte, seagrass meadows are exploited year-round mainly by juvenile and adult green turtles while inter-specific competition and predation are limited (Roos et al. 2005; Taquet et al. 2006). This provides the opportunity to test for the first time the hypothesis that in a multispecific seagrass meadow, green turtles of different size may adjust their distribution and habitat use differently in relation to food resource quality and abundance. We first investigated the structure of the seagrass meadow in terms of species composition and distribution. For the second step, we assessed the structure and distribution of the local green turtle population and studied their habitat use and food selection. Our study is novel in that we assessed the links between a structure of a multispecific seagrass meadow and the distribution of green turtles of different size in their natural environment.

\section{Materials and methods}

This study was conducted between October 2004 and July 2005 in the bay of N'Gouja, southern coasts of Mayotte Island (12 $\left.{ }^{\circ} 58^{\prime} \mathrm{S}, 45^{\circ} 05^{\prime} \mathrm{E}\right)$, Comoros Archipelago, Mozambique Channel, SWIO (Fig. 1). This bay hosts a multispecific seagrass meadow and has been reported to be an important feeding ground for green turtles (Roos et al. 2005). At N'Gouja, the seagrass bottom slopes progressively seawards, never exceeding $4 \mathrm{~m}$ depth even at the highest tide level, until a coral reef on the inner reef slope shore $(1.00 \pm 0.04 \mathrm{~m}$ of depth difference from the shore to the coral reef). Within a $24 \mathrm{~h}$ period, the seagrass meadow is often partially or completely emerged, but is always accessible for direct observations.

\section{Seagrass monitoring}

To measure seagrass biomass and density, the study area was divided into 54 sectors 
(50 x $50 \mathrm{~m}$ each) among which 24 quadrats $(20 \mathrm{~cm} \times 20 \mathrm{~cm}$ each) were randomly distributed in February-March 2005 (Fig. 1). The position of each quadrat was recorded using a handheld global positioning system (GPS GeoXT ${ }^{\mathrm{TM}}$ handheld Trimble GeoExplorer, ED Electronique, Sainte Savine, France; precision $\pm 2 \mathrm{~m}$ ). Substrate and associated vegetation were collected using a spade. For each quadrat we identified the dominant substrate type (mud, sand, and detrital matter) using a manual granulometry assessment (McKenzie et al. 2007). Seagrass collected from a quadrat was washed under fresh water to remove sediment remains, before being separated according to species (based on McMillan 1983; Waycott et al. 2004; Jacobs et al. 2006). Leaf-blades sampled were dried between two sheets of linen before the fresh biomass was weighed (fresh weight, FW) with an electronic spring scale (DL-501 Denver Instruments, Colorado, USA; precision $\pm 0.1 \mathrm{~g}$ ). In addition, we estimated the leaf density of quadrats by counting leaves on underwater still-pictures. Due to camera failure, the leaf density of only 10 of the 24 quadrats was counted. Leaf biomass was expressed both in fresh weight and in dry weight (DW) using the following conversion equation established after freeze-drying $50.4 \mathrm{gFW}$ and $63.9 \mathrm{gFW}$ of the two most abundant species, Halodule uninervis and Syringodium isoetifolium, respectively: DW $=13.3( \pm 5.6) \%$ FW (Eqn 1).

In April 2005, seagrass distribution was assessed by the same observer (KB) using the phyto-ecological method developed by Braun-Blanquet (1964). A series of four snorkel transects ( $4 \mathrm{~m}$ wide each) was conducted along the depth gradient, i.e. perpendicular to shore (Fig. 1). Along each transect, the vegetation was continuously scanned to identify changes in at least one of the following parameters: seagrass species composition (based on McMillan 1983; Waycott et al. 2004; Jacobs et al. 2006), relative cover abundance of each seagrass species (based on Braun-Blanquet 1964), seagrass coverage, and nature of substrate. Seagrass coverage was visually defined by the proportion of substrate covered by vegetation. Relative cover abundance of each seagrass species and seagrass coverage were estimated using a visual index, la (abundance index) and Ic (coverage index), respectively. Indices $\mathrm{la}$ and Ic were scaled from 1 to 5 , corresponding to abundance/coverage classes of [0\%; 5\%], [5\%; 25\%], [25\%; 50\%], [50\%; 75\%], [75\%; $100 \%]$. Transect stations were defined as transect sections where all these parameters were constant. A total of 23 transect stations were identified accordingly: For each transect station a substrate sample was analysed by manual granulometry assessment (McKenzie et al. 2007) and seagrass communities were identified as areas of similar seagrass-specific composition and abundance before being geopositionned using the GPS.

\section{Green turtle monitoring}

The seagrass meadow of N'Gouja is frequented by a population of both immature and mature green turtles during daytime and sometimes during full moon nights (Taquet et al. 2006). Between October 2004 and March 2005, 29 turtles of this population have been individually tagged with numbered Monel metal tags on the front flippers (National Band and Tag Company, Newport, Kentucky, USA) as part of a monitoring program of the Department of Agriculture and Forestry of Mayotte and General Council of Mayotte. Since neither the actual status (immature versus adult), nor the sex of turtles occurring $n$ the study site could be assessed using external morphology. Accordingly, individuals were classified depending on their carapace length: For each individual, the standard curve carapace length (SCCL, from the nuchal scute to the caudal scute, on the midline of the shell) was measured using a flexible measuring tape $( \pm 0.5 \mathrm{~cm})$. This permitted to distinguish two classes of individuals: individuals with $\mathrm{SCCL}<80 \mathrm{~cm}(48.9 \pm 2.4 \mathrm{~cm}$, ranging from 39 to $58.5 \mathrm{~cm}, \mathrm{n}=7$ individuals) and individuals with SCCL $>80 \mathrm{~cm}(94.5 \pm 2.5 \mathrm{~cm}$, from 83 to $105 \mathrm{~cm}, \mathrm{n}=22)$, hereafter referred as small and large individuals. The bay of N'Gouja is also frequented by swimming and snorkelling tourists. Even if turtle-human interactions occur, preliminary internal studies indicate that turtles do not change their behaviour when feeding on the seagrass meadow 
when swimmers are close. Yet, to prevent any bias, analyses did not consider observations performed during tourist-attracting days such as week-ends and holidays.

From March to June 2005, 28 snorkelling censuses were conducted by KB to monitor the green turtle population of the study site. Censuses were distributed throughout the day on a two-hour basis, i.e. at 06:00 - 08:00 ( $n=4$ censuses), 08:00 - 10:00 ( $n=5$ censuses), 10:00 12:00 ( $n=5$ censuses), 12:00 - 14:00 ( $n=4$ censuses), 14:00 - 16:00 ( $n=5$ censuses) and 16:00 - 18:00 ( $n=5$ censuses). This corresponded to four different tide regimes associated with following depth-classes: $0.7-1 m$ ( $n=4$ censuses), $1-2 m$ ( $n=12$ censuses), $2-3 m$ (n

$=10$ censuses $)$ and $3-4 \mathrm{~m}(\mathrm{n}=2$ censuses). During each census, the snorkeler was following a standardised route across the seagrass meadow (Fig. 1). Every time a turtle was encountered, its identity (when tagged) and its class size (small or large) were noted. At the beginning and end of each 1-h census, minimum water depth (close to the beach) and maximum water depth (close to the coral reef) of the seagrass meadow were assessed using a loaded tape measure. To establish turtle encounter rate during a census (number of turtles encountered per $\mathrm{m}^{2}$ and per hour), the total area scanned for a given census, which was dependant of the water visibility, was estimated at the beginning and at end of each census using a horizontal tape measure, held perpendicular to the route taken over the seagrass meadow. To investigate the spatial distribution of green turtles according to size classes and to food distribution, we recorded the GPS position of each turtle encountered during five previously described censuses. All visual observations showed with no exception that turtles were actively feeding when on the seagrass meadow, consistent with unpublished data showing that at N'Gouja, all dives performed by green turtles on the seagrass meadow are feeding dives (Ballorain et al. in prep). Accordingly, we considered that the observed pattern of habitat use of the seagrass meadow communities by green turtles was indicative of foraging.

\section{Data analyses}

Spatial analyses were performed using MapInfo Professional 8.0 (MapInfo Corporation, USA, 2005). Statistical analyses were conducted using Systat 9.0 (SPSS Inc., USA, 1998). Values are expressed as mean \pm standard deviation $( \pm S D)$. Before conducting parametric analysis, all data were tested for normality and homogeneity of variances. Significance was accepted when $p$-value $<0.05$.

The most frequent seagrass associations within the seagrass meadow were assessed using Factorial Correspondence Analysis (FCA) ordination technique using transect stations data. A General Linear Model (GLM) was used to test for the association between turtle distribution, time of the day and tidal state, with turtle encounter rate as the dependent variable, while time of the day (06:00 - 18:00) and tide (mean depth: $0.7-3.3 \mathrm{~m}$ ) were taken as independent variables. Chi-Square $X^{2}$ test and Neu post-hoc test (Neu et al. 1974) were performed to test for habitat preferences of green turtles in relation to their size-classes.

\section{Results}

\section{Seagrass distribution}

The study site consisted of a $133500 \mathrm{~m}^{2}$ meadow area (Fig. 1). We found four major substrate types that occurring along the depth gradient seawards, from (1) muddy to (2) sandy- muddy, (3) sandy, and (4) sandy-detrital matter. The site was dominated by sandy sediment, which occurred in $46 \%$ of the 24 random quadrats $\left(x^{2} 3=45.8, p<0.001\right)$ and in $74 \%$ of the four transects $\left(X^{2} 3=76.2, p<0.001\right)$ (Appendices 1 and 2$)$. 
Eight seagrass species were observed at N'Gouja: Halophila ovalis (R.Br.) Hook. f., Halodule uninervis (Forsk.) Aschers., Zostera muelleri subsp. capricorni (Aschers.) Jacobs (basionym: Zostera capricorni Aschers.), Syringodium isoetifolium (Aschers.) Dandy, Cymodocea serrulata (R. Brown) Aschers. and Magnus, Cymodocea rotundata (Hemprich and Ehrenb.) Aschers. and Schweinf, Thalassia hemprichii (Ehrenberg) Aschers., and Thalassodendron ciliatum (Forsk.) den Hartog (Appendix 1). Of these eight species, however, two were rarely observed: Thalassodendron ciliatum was recorded neither in the random quadrats nor during transects and Zostera capricorni was only recorded in one single quadrat (\# 8) and not during transects. Halodule uninervis is a polymorphic-leafed species with an environmentally modifiable leaf width and leaf tip ranging from bicuspidate to tridentate (McMillan 1983): These two morphs were observed at N'Gouja and are referred hereafter as $H$. uninervis Type 1 (T1) and $H$. uninervis Type 2 (T2), respectively. These two morphs $T 1$ and T2 were considered separately in the analyses since their respective distribution differed (see also Lanyon and Sanson 2006).

When considering the 23 transect stations, $H$. uninervis (both types) and $S$. isoetifolium were the most frequently (co-) dominant species with an occurrence of $51.5 \%$ and $33.3 \%$, respectively $\left(X^{2} 5=139.6, p<0.001\right.$, Appendix 2$)$. Consistently, in the 24 random quadrats, $55 \%$ of the total seagrass biomass was composed by the same two species $H$. uninervis and $S$. isoetifolium, with $H$. uninervis T2 being the most abundant $\left(28 \%, X^{2} 7=57.59, p<0.001\right.$, Appendix 1). Overall seagrass leaf density was $5781 \pm 1691$ leaves $\mathrm{m}^{-2}$, which corresponds to an above ground seagrass biomass of $145.4 \pm 108.0 \mathrm{gFW} \mathrm{\textrm {m } ^ { - 2 }}$, resulting in an average of 19.4 tons FW for the entire $133500 \mathrm{~m}^{2}$ meadow.

Transect surveys showed that the six major seagrass species were distributed along a depth gradient perpendicular to shore (Appendix 2). We investigated the potential species association within the meadow by performing a FCA using transect stations $(n=23)$ and seagrass species/morphs $(n=7)$ as continuous variables (Appendix 1 and Fig. 2). The first two axes of the FCA extracted $92.5 \%$ of the total inertia of the dataset. Variables appear with a parabolic projection, generated by a quadratic correlation between the first two axes, illustrative of a Guttman-effect. This shows a structure of unidimensional ordinal data along the first axis, while the second axis opposes intermediates and extreme variables (Benzecri 1973). A clear gradient is drawn along the first axis: from left to right, the variables are arranged from the closest to the furthest point from shore. Accordingly, the FCA identified four seagrass communities that differed by their respective distance from shore (Figs 2 and 3, Appendix 2). Moving seaward from shore (i.e. towards greater depths), we identified four successive communities ( $\mathrm{C} 1$ to $\mathrm{C} 4$, successively). These communities were typically dominated by one or two species/morphs and were named accordingly (Appendix 2): $\mathrm{H}$. uninervis $T 1$ (C1, $9420 \mathrm{~m}^{2}$, i.e. $7 \%$ of the total study area), H. uninervis $T 2\left(\mathrm{C} 2,47302 \mathrm{~m}^{2}\right.$, i.e. $35 \%), H$. uninervis T2 and S. isoetifolium $\left(\mathrm{C} 3,58444 \mathrm{~m}^{2}\right.$, i.e. $\left.44 \%\right)$, and S. isoetifolium (C4, $18333 \mathrm{~m}^{2}$, i.e. 14\%). Overall, the meadow was dominated by C3, which accounted for $44 \%$ of the total meadow surface area $\left(x^{2} 3=36.4, p<0.001\right)$. Seagrass coverage increased with distance from shore (mean Ic: 2 to 3 for C1; 3 to 4 for C2; 4 to 5 for C3 and C4). Each seagrass community was also associated with a specific type of substrate: muddy-sandy $\left(C 1, X^{2} 2=53.1, p<0.001\right)$, sandy $\left(C 2, X^{2} 2=89.2, p<0.001\right)$, sandy $\left(C 3, x^{2} 2=200, p<\right.$ $0.001)$, and sandy/sandy-detrital substrate $\left(C 4, X^{2}=50.2, p<0.001\right)$.

\section{Green turtle distribution}

During the 28 snorkelling censuses an average of $11242 \pm 4362 \mathrm{~m}^{2}$ were covered within 55.8 \pm 1.0 min ( $n=28$ censuses). The mean turtle encounter rate on the seagrass meadow was $23.9 \times 10^{-4} \pm 10^{-4}$ turtles $\mathrm{m}^{-2}$, with significantly more large turtles (67.1\%) being sighted than small individuals $\left(32.9 \%, X^{2} 1=11.7, p<0.001\right)$. Encounter rate did not differ neither with time of day nor with water depth during daytime $\left(F_{5}=0.853, p=0.619\right.$, Table 1$)$. Turtle distribution, however, was not random within the four seagrass communities and differed between small and large individuals $\left(x^{2} 3=20.19, p<0.001\right)$. Large turtles occurred mainly in 
community $\mathrm{C} 4$ and not at all in $\mathrm{C} 1\left(\mathrm{X}^{2} 3=44.77, \mathrm{p}<0.001\right)$, whereas small turtles were found equally in all four seagrass communities $\left(x^{2} 3=4.46, p=0.215\right)$. Yet when the relative surface area of each seagrass community was taken into account, large turtles preferentially occurred in C4 $\left(X^{2} 3=92.75, p<0.001\right)$, while small individuals preferentially occurred in $\mathrm{C} 1$ and C4 $\left(X^{2} 3=38.21, p<0.001\right)$ (Fig. 3). Whatever the seagrass community, green turtles were observed to crop dominant local seagrass species.

\section{Discussion}

The seagrass meadow of N'Gouja consists in a 13 ha shallow area representing about 19 tons FW of seagrass. This is six-fold greater than biomass reported for tropical seagrass meadows in U.S. Virgin Islands exploited by green turtles (Williams 1988), but only $10 \%$ of what has been reported in tropical seagrass meadows not exploited by green turtles (Duarte and Chiscano 1999). The seagrass meadow of N'Gouja hosts eight out of the eleven seagrass species recently reported around the entire island of Mayotte (B.K., C.S., B.J., E.M., G.H., G.J-Y. unpublished data), with Halodule uninervis and Syringodium isoetifolium being the most abundant, and Zostera capricorni being reported for the first time in this area. Accordingly, as far as seagrass are concerned, N'Gouja is representative of Mayotte's marine biodiversity, and its production may contribute to the permanent presence of green turtles feeding there year-round (Roos et al. 2005, Taquet et al. 2006).

At N'Gouja, the seagrass species are distributed along the depth gradient, concurrent with the seaward distance from shore. Such distribution is consistent with the classical distribution pattern of aquatic plants where light, temperature, turbulence, and immersion regimes determine vertical distribution and occurrence of seagrass (Koch and Beer 1996, Bandeira 2002b). Importantly, the observed seagrass distribution results in four major seagrass communities occurring in successive strips parallel to the shore (Fig. 3). These four seagrass communities can be identified by the presence or absence of differential seagrass species: Close to shore, C1 community was the less extended community characterized by $H$. uninervis and $\mathrm{H}$. ovalis, two pioneer seagrass species tolerant to abiotic conditions (den Hartog 1970; Kuo et al. 2001). The low seagrass density observed in this first community may result from the combined effects of high turbidity due to sand movement, elevated temperature and salinity due to the long emersion times (Abal et al. 1994; Grice et al. 1996), and disturbance by swimmers. Of the two morphs of $H$. uninervis found in this study, T1 (narrow leaves with bicuspidate leaf tips) dominated in areas that are regularly emerged, which is consistent with the finding that this morph has a greater resistance to high temperatures than the wider-leafed T2 morph (Philips and Lewis 1983; McMillan 1984). When heading seawards, seagrass diversity and density increased with increasing depth and water transparency, indicating that conditions were more stable for the communities furt her from shore. Consistent with this, C4 community situated close to the slope 319 was characterised by S. isoetifolium, an eurythermic species (Phillips 1960), previously reported to preferentially occur in relatively clear waters (Terrados et al. 1998). All other seagrass species were less abundant than the former two species, with Thalassia hemprichii, Cymodocea rotundata and Cymodocea serrulata occurring in a scattered way all over the seagrass meadow.

We show that at N'Gouja, green turtles occur all over the seagrass meadow throughoutthe day as long as the tidal cycle gives them access to it. This is consistent with Taquet et al. (2006) who reported a tidal-driven occurrence of green turtles on N'Gouja meadow. Importantly, all visual observations showed with no exception that turtles were actively feeding when on the seagrass meadow, consistent with unpublished data showing that at N'Gouja, all dives performed by green turtles on the seagrass meadow are feeding dives (Ballorain et al. in prep). Accordingly, we considered that the observed pattern of habitat use of the seagrass meadow communities by green turtles was indicative of foraging, and that the differential use of seagrass communities reflected diet selection. When considering the 
relative surface area of each seagrass community, both small and large green turtles preferentially frequented the most seaward C4 community (14\% of the total meadow surface area) with respectively $29 \%$ and $45 \%$ of sightings occurring on C4. Additionally, only small turtles occurred in the near to shore $\mathrm{C} 1$ community ( $7 \%$ of the total meadow surface area) with $16 \%$ of sightings of small turtles occurring there. This differential habitat use by turtles of different size suggests differential food selection at the scale of the seagrass meadow. It is however also interesting to note that overall, both small and large turtles occur at similar level (45\% of sightings) in C1/C4, and in C4 communities, respectively. Accordingly, small and large turtles similarly occur in the remaining $\mathrm{C} 2$ and $\mathrm{C} 3$ communities with no preference when surface areas are taken into account, suggesting that these communities provide food of similar interest for both types of turtles. The common preference for $\mathrm{C} 4$ for both small and large turtles may result from the dominant presence and extensive coverage of $S$. isoetifolium reported to by particularly rich in nitrogen compared to other tropical seagrass species (Aragones 1996). Additionally S. isoetifolium has cylindrical, very brittle leaves (Aioi and Pollard 1993), which make digestion easier by the relatively greater leaf surface area produced after bolus processing (Bjorndal et al. 1990). Similarly, $H$. uninervis $T 1$ and $H$. ovalis dominating $\mathrm{C} 1$ community reportedly are of great nutritional, highly digestible, value compared to most other tropical seagrass species, with a relatively strong regenerative potential (Aragones 1996; Sheppard et al. 2007; de longh et al. 2007). As such, H. uninervis and $H$. ovalis have been reported to be frequently exploited by grazers such as green turtles (Bjorndal 1997; Hasbùn et al. 2000) and dugongs (de longh et al. 2007). By preferentially exploiting seagrass species that occur in great density, that are rich in nitrogen, and that are easily digestible, green turtles may compensate for their intrinsically nutrient-poor herbivorous diet, as reported in other herbivores (Fenchel and Jorgensen 1977; Mattson 1980; White 1985).

The fact that large turtles were never sighted in C1 community suggests that seagrass composition and abundance are not the only drivers of habitat use in green turtles. This is supported by the observation of both small and large turtles exploiting the two remaining C2 and C3 communities at a similar level, regardless their relative surface area within the meadow. In our study, differential habitat use in green turtles of different size implies large individuals diving to deeper depths. Previous studies report lung-regulated buoyancy control in sea turtles (Hays et al. 2004), with larger individuals having higher diving capabilities thanks to larger lung capacities (Hochscheid et al. 2003). Yet, since depth on the study site only ranges from 1 to $4 \mathrm{~m}$, diving physiology may not be a prime determinant of the observed differential habitat use in our case. Thermal conditions may more likely contribute to differential habitat use between small and large turtles. Temperature plays a major role in ectotherms such as sea turtles, since it drives physiological processes (Mrosovsky 1980; Spotila et al. 1997; Seebacher and Franklin 2005), including digestion with high temperature increasing digestion rate (Parmenter 1980; Wikelski and Hau 1995). Behavioural thermoregulation is reported in many reptiles (Brattstrom 1965) and several studies demonstrated the role of thermal environment in habitat use by reptiles. For example, lizards adjust their body temperature through altitudinal location or shuttling between sun and shade (Adolph 1990; Belliure et al. 1996) and marine iguanas thermoregulate using wind protected sites (Buttemer and Dawson 1993). In sea turtles, loggerhead and green turtles bask on land and at sea surface to increase their body temperature (Sapsford and Van der Riet 1979; Whittow and Balazs 1982). In sea turtles, digestion capacities are greater in large than smaller, i.e. younger, individuals due to incomplete intestinal flora of the latter (Bjorndal 1997). Accordingly, we suggest that small turtles increase their digestion rate by spending a significant amount of their time in relatively shallower and warmer waters close to shore. By preferentially selecting nearshore, relatively shallow and warm C1 community, small (i.e. young) turtles may also compensate for their relatively high energy requirements associated with growth (Bouchard and Bjorndal 2006), suggesting the pivotal ecological role of shallow and nearshore habitats for growing green turtles. Size-related difference in behavioural exploitation of the thermal environment has been previously reported in ectotherms as such western toads, insular lizard and marine iguana (Lillywhite et al. 1973; Castilla and Bauwens 
1991; Buttemer and Dawson 1993). Similar temperature-driven physiological processes may contribute to the observed differential habitat use in green turtles of different size at N'Gouja. Additional studies are required to investigate the thermal preferences in green turtles and their implications in terms of physiology and behaviour. Understanding the factors driving spatial distribution and habitat use in green turtles contributes to identify critical habitats and to provide scientific bases for the management and the conservation of endangered green turtles and related habitats.

\section{Acknowledgements}

We are grateful to the Department of Agriculture and Forestry of Mayotte (DAF), the General Council of Mayotte (CDM) and the Jardin Maoré Hotel for their financial and technical support. We especially thank D. Chanfi, K. Ahamed, M. Quillard and A. Mari (CDM), R. Rolland, J-P. Arnaud, A. Jamon (DAF), P. Stefanica, F. Bourgeois and B. Fichou (Jardin Maoré), J. Turquet (ARVAM), J.-P. Robin (CNRS IPHC, Strasbourg), the Oulanga na Nyamba Association and many volunteers for technical and field assistance. Funding was also provided by the Regional Council of Reunion Island, the European Social Fund (ESF), the French National Agency of Research (ANR "ESTVOI" project) and Kelonia. Finally, we would like to thank Simon Benhamou (CNRS CEFE, Montpellier) and the anonymous reviewers for their helpful comments on this manuscript.

\section{References}

Abal EG, Loneragan NR, Bowen P, Perry CJ, Udy JW, Dennison WC (1994) Physiological and morphological reponses of the seagrass Zostera capriconi Aschers to light intensity. J Exp Mar Biol Ecol 178:1123-1129

Adolph SC (1990) Influence of behavioral thermoregulation on microhabitat use by two Sceloporus lizards. Ecology 71:315-327

Aioi K, Pollard PC (1993) Biomass, leaf growth and loss rate of the seagrass Syringodium isoetifolium on Dravuni Island, Fiji. Aquat Bot 46:283-292

André J, Gyuris E, Lawler IR (2005) Comparison of the diets of sympatric dugongs and green turtles on the Orman Reefs, Torres Straight, Australia. Wildlife Res 32:53-62

Aragones LV (1996) Dugongs and Green Turtles: Grazers in the tropical seagrass system. PhD dissertation, James Cook University of North Queensland, Australia

Bandeira SO (2002a) Leaf production rates of Thalassodendron ciliatum from rocky and sandy habitats. Aquat Bot 72:13-24

Bandeira SO (2002b) Diversity and distribution of seagrasses around Inhaca Island, southern Mozambique. S Afr J Bot 68:191-198

Barclay RMR (1991) Population structure of temperate zone insectivorous bats in relation to foraging behaviour and energy demand. J Anim Ecol 60:165-178

Baumont R (1996) Palatability and feeding behaviour in ruminants. INRA Productions Animales 9:349-358

Belliure J, Diaz JA, Carrascal LM (1996) Covariation of thermal biology and foraging mode in two Mediterranean lacertid lizards. Ecology 77:1163-1173

Benavides AG, Cancino JM, Ojeda FP (1994) Ontogenetic change in the diet of Aplodactylus punctatus (Pisces: Aplodactylidae): an ecophysiological explanation. Mar Biol 118:1-5.

Benzecri JP (1973) L'analyse des données. Tome II. L'analyse des correspondances. Dunod, Paris

Bergvall UA, Lemar O (2005) Plant secondary compounds and the frequency of food types affect food choice by mammalian herbivores. Ecology 86:2450-2460 
Bjorndal KA, Bolten AB, Moore JE (1990) Digestive Fermentation in Herbivores: Effect of Food Particle Size. Physiol Zool 63:710-721

Bjorndal KA (1997) Foraging ecology and nutrition of sea turtles. In: Lutz PL, Musick JA (eds) The biology of sea turtles. CRC Press, Boca Raton, pp 199-231

Blanchard P, Sabatier R, Fritz H (2008) Within-group spatial position and vigilance: a role also for competition? The case of impalas (Aepyceros melampus) with a controlled food supply. Behav Ecol Sociobiol 62:1863-1868

Bouchard SS, Bjorndal KA (2006) Ontogenetic Diet Shifts and Digestive Constraints in the Omnivorous Freshwater Turtle Trachemys scripta. Physiol Biochem Zool 79:150-158.

Brand-Gardner SJ, Lanyon JM, Limpus CJ (1999) Diet selection by immature green turtles, Chelonia mydas, in subtropical Moreton Bay, South-east Queensland. Aust J Zool 47:181191

Brattstrom BH (1965) Body temperatures of reptiles. Am Midl Nai 73:376-422

Braun-Blanquet J (1964) Pflanzensoziologie, Grundzüge der Vegetationskunde. Aufl. Springer, Wien-New York

Buttemer WA, Dawson WR (1993) Temporal pattern of foraging and microhabitat use by Galapagos iguanas, Amblyrhynchus cristatus. Oecologia 96:56-64

Castilla AM, Bauwens D (1991.) Thermal biology, microhabitat selection, and conservation of the insular lizard Podarcis hispanica atrata. Oecologia 85:366-374

Cézilly F, Benhamou S (1996) Les stratégies optimales d'approvisionnement (Optimal foraging strategies a review). Rev Ecol - Terre Vie 51:43-86

Coyne MS (1994) Feeding ecology of subadult green sea turtles in South Texas waters. PhD dissertation, Texas A\&M University, USA

de longh HH, Kiswara W, Kustiawan W, Loth PE (2007) A review of research on the interactions between dugongs (Dugong dugong Müller 1776) and intertidal seagrass beds in Indonesia. Hydrobiologia 591:73-83

den Hartog C (1970) The Seagrasses of the World. North Holland Publication, Amsterdam, London

Drescher M, Heitkönig MAI, Van den Brink PJ, Prins HHT (2006) Effects of sward structure on herbivore foraging behaviour in a South African savanna: An investigation of the forage maturation hypothesis. Austral Ecol 31:76-87

Duarte CM, Chiscano CL (1999) Seagrass biomass and production: a reassessment. Aquat Bot 65:159-174

Durtsche RD (2004) Ontogenetic variation in digestion by the herbivorous lizard Ctenosaura pectinata. Physiol Biochem Zool 77:459-470

Fenchel TM, Jorgensen BB (1977) Detritus food chains of aquatic ecosystems: The role of bacteria. Adv Microb Ecol 1:1-58

Forbes GA (1996) The diet and feeding ecology of the green sea turtle (Chelonia mydas) in algal-based coral reef community. PhD dissertation, James Cook University, Australia

Fossette S, Gaspar P, Handrich Y, Le Maho Y, Georges J-Y (2008) Dive and beak movement patterns in leatherback turtles Dermochelys coriacea during internesting intervals in French Guiana. J Anim Ecol 77:236-246

Frank DA, McNaughton SJ, Tracy BF (1998) The Ecology of the Earth's Grazing Ecosystems. BioScience 48:513-521

Georges J-Y, Tremblay Y, Guinet C (2000) Seasonal diving behaviour in lactating subantarctic fur seals on Amsterdam Island. Polar Biol 23:59-69

Grice AM, Loneragan NR, Dennison WC (1996) Light intensity and the interactions between physiology, morphology and stable isotope ratios in five species of seagrass. J Exp Mar Biol Ecol 195:91-110

Gullström M, de la Torre Castro M, Bandeira SO, Björk M, Dahlberg M, Kautsky N, Rönnbäck P, Öhman MC (2002) Seagrass Ecosystems in the Western Indian Ocean. Ambio 31:588-596

Hasbùn CR, Lawrence AJ, Samour JH, Al-Ghais SM (2000) Preliminary observations on the biology of green turtles, Chelonia mydas, from the United Arab Emirates. Aquat Conserv 10:311-322 
Hays GC, Metcalfe JD, Walne AW (2004) The implications of lung-regulated buoyancy control for dive depth and duration. Ecology 85:1137-1145

Heithaus MR, Frid A, Wirsing AJ, Fourqurean JW, Burkholder D, Thomson J, Befder L. (2007) State-dependent risk-taking by green sea turtles mediates top-down effects of tiger shark intimidation in a marine ecosystem. J Anim Ecol 76:837-844

Herpol C (1967) Study on the proteolytic activity of the digestive tract of different species of birds in relation to their feeding habits. J Comp Physiol 57:209-217

Hochscheid S, Bentivegna F, Speakman JR (2003) The dual function of the lung in chelonian sea turtles: buoyancy control and oxygen storage. J Exp Mar Biol Ecol 297:123-140

Jacobs SWL, Les DH, Moody ML (2006) New combinations in Australasian Zostera (Zosteraceae). Telopea 11:127-128

Jupp BP, Durako MJ, Kenworthy WJ, Thayer GW, Schillak L (1996) Distribution, abundance, and species composition of seagrasses at several sites in Oman. Aquat Bot 53:199-213

Koch EW, Beer S (1996) Tides, light and the distribution of Zostera marina in Long Island Sound, USA. Aquat Bot 53:97-107

Krebs JR, Davies NB (1997) Behavioural ecology: an evolutionnary approach, 4rd edn. Editions Blackwell Science Ltd., Oxford

Kuo J, Shibuno T, Kanamoto Z, Noro T (2001) Halophila ovalis (R. Br.) Hook. f. from a submarine hot spring in southern Japan. Aquat Bot 70:329-335

Lanyon JM, Sanson GD (2006) Mechanical disruption of seagrass in the digestive tract of the dugong. J Zool (Lond) 270:277-289

Le Boeuf BJ, Crocker DE, Costa DP, Blackwell SB, Webb PM, Houser DS (2000) Foraging Ecology of Northern Elephant Seals. Ecol Monogr 70:353-382

León YM, Bjorndal KA (2002) Selective feeding in the hawksbill turtle, an important predator in coral reef ecosystems. Mar Ecol Prog Ser 245:249-258

Lillywhite HB, Licht $P$, Chelgren $P$ (1973) The role of behavioral thermoregulation in the growth energetics of the toad, Bufo boreas. Ecology 54:375-383

López-Mendilaharsu M, Gardner SC, Riosmena-Rodriguez R, Seminoff JA (2008) Diet selection by immature green turtles (Chelonia mydas) at Bahía Magdalena foraging ground in the Pacific Coast of the Baja California Peninsula, México. J Mar Biol Assoc UK 88:641647

MacArthur RH, Pianka ER (1966) On the optimal use of a patchy environment. Am Nat 100:603-609

Mattson WJ, Jr (1980) Herbivory in relation to plant nitrogen content. Annu Rev Ecol Syst 11:119-161

McKenzie LJ, Campbell SJ, Vidler KE, Mellors JE (2007) Seagrass-Watch: Manual for Mapping \& Monitoring Seagrass Resources. Seagrass-Watch HQ, Cairns

McMillan C (1983) Morphological diversity under controlled conditions for the Halophila ovalis- $H$. minor complex and the Halodule uninervis complex, from Shark Bay, Western Australia. Aquat Bot 17:29-42

McMillan C (1984) The distribution of tropical seagrasses with relation to their tolerance of high temperatures. Aquat Bot 19:369-379

Mobley KB, Fleeger W (1999) Diet of Scartella cristata: An artificial habitat-associated blenny (Pisces: Blenniidae). Vie Milieu 49:221-228

Moran KL, Bjorndal KA (2007) Simulated green turtle grazing affects nutrient composition of the seagrass Thalassia testudinum. Mar Biol 150:1083-1092

Mrosovsky N (1980) Thermal biology of sea turtles. Am Zool 20:531-547

Nagelkerken I, Dorenbosch M, Verberk WCEP, Cocheret de la Morinière E, van der Velde G (2000) Importance of shallow-water biotopes of a Caribbean bay for juvenile coral reef fishes: patterns in biotope association, community structure and spatial distribution. Mar Ecol Prog Ser 202:175-192

Neu CW, Byers CR., Peek JM (1974) A technique for analysis of utilization-availability data. J Wildlife Manage 38:541-545 
Newell RE, Koch EW (2004) Modeling Seagrass Density and Distribution in Response to Changes in Turbidity Stemming from Bivalve Filtration and Seagrass Sediment Stabilization. Estuaries 27:793-806

Parmenter RR (1980) Effects of Food Availability and Water Temperature on the Feeding Ecology of Pond Sliders (Chrysemys s. scripta). Copeia 3:503-514

Pellew RA (1984) The feeding ecology of a selective browser, the giraffe (Giraffa camelopardalis tippelskirchl). J Zoo1 202:57-81

Peralta G, Pérez-Lloréns JL, Hernández I, Vergara JJ (2002) Effects of light availability on growth, architecture and nutrient content of the seagrass Zostera noltii Hornem. J Exp Mar Biol Ecol 269:9-26

Phillips RC (1960) Observations on the ecology and distribution of the Florida seagrasses. Florida State Board of Conservation, Marine Laboratory. Professional Papers Series No. 2. St. Petersberg, Florida.

Phillips RC, Lewis RL (1983) Influence of environmental gradients on variations in leaf widths and transplant success in North American seagrasses [Zostera marina, eelgrass, Thalassia testudinum, turtlegrass, habitats]. Aquat ecol 17:59-68.

Pinaud D, Cherel Y, Weimerskirch H (2005) Effect of environmental variability on habitat selection, diet, provisioning behaviour and chick growth in yellow-nosed albatrosses. Mar Ecol Prog Ser 298:295-304

Roos D, Pelletier D, Ciccione S, Taquet M, Hughes G (2005) Aerial and snorkelling Census Techniques (observations) for estimating green turtle abundance on foraging areas: a pilot study in Mayotte Island (Indian Ocean). Aquat Living Resour 18:193-198

Ruckstuhl KE (1998) Foraging behaviour and sexual segregation in bighorn sheep. Anim Behav 56:99-106

Sapsford CW, Van der Riet M (1979) Uptake of solar radiation by the sea turtle, Caretta caretta, during voluntary basking. Comp Biochem Physiol A63:471-474

Seber GAF (1982) The estimation of animal abundance and related parameters, 2nd edn. Macmillan, New York

Seebacher F, Franklin CE (2005) Physiological mechanisms of thermoregulation in reptiles: a review. J Comp Physiol B 175:533-541

Sheppard JK, Lawler IR, Marsh H (2007) Seagrass as pasture for seacows: Landscape-level dugong habitat evaluation. Estuar Coast Shelf S 71:117-132

Short FT (1987) Effects of sediment nutrients on seagrasses: Literature review and mesocosm experiment. Aquat Bot 27:41-57

Spotila JR, O'Connor MP, Paladino FV (1997) Thermal Biology. In: Lutz PL, Musick JA (eds.) The Biology and of Sea Turtles. CRC Press, Boca Raton, pp 297-314

Stephens DW, Krebs JR (1986) Foraging Theory, Princeton University Press, New Jersey

Taquet C, Taquet M, Dempster T, Soria M, Ciccione S, Roos D, Dagorn L (2006) Foraging rhythms of the green sea turtle (Chelonia mydas) on seagrass beds in N'Gouja Bay, Mayotte (Indian Ocean), determined by acoustic transmitters and listening station. Mar Ecol Prog Ser 306:295-302.

Terrados J, Duarte CM, Fortes MD, Borum J, Agawin NSR, Bach S, Thampanya U, KampNielsen L, Kenworthy WJ, Geertz-Hansen O, Vermaat J (1998) Changes in Community Structure and Biomass of Seagrass Communities along Gradients of Siltation in SE Asia. Estuar Coast Shelf S 46:757-768

van Wieren SE (1996) Do large herbivores select a diet that maximizes short-term energy intake rate? Forest Ecol Manag 88:149-156

Vourc'h G, De Garine-Wichatitsky M, Labbé A, Rosolowski D, Martin JL, Fritz H (2002) Monoterpene effect on feeding choice by deer. J Chem Ecol 28:2411-2427

Wakibya JG (1995) The potential human-induced impacts on the Kenya seagrasses. UNESCO Reports in Marine Science 66:176-187

Wallis de Vries MF (1996) Effects of resource distribution patterns on ungulate foraging behaviour: a modelling approach. Forest Ecol Manag 88:167-177

Waycott M, McMahon K, Mellors J, Calladine A, Kleine D (2004) A guide to tropical seagrasses of the Indo-West Pacific, James Cook University, Townsville 
White TCR (1985) When is a herbivore not a herbivore? Oceologia 67:596-597

White, TCR (1993) The inadequate environment: nitrogen and the abundance of animals. Springer-Verlag, New York, USA

Whittow GC, Balazs GH (1982) Basking behaviour of the Hawaiian green turtle (Chelonia mydas). Pac Sci 36:129-139

Wikelski M, Hau M (1995) Is there an endogenous tidal foraging rhythm in marine iguanas? J Biol Rhythm 10:345-360

Williams SL (1988) Thalassia testudinum productivity and grazing by green turtles in a highly disturbed seagrass bed. Mar Biol 98:447-455

Wolf JBW, Kauermann G, Trillmich F (2005) Males in the shade: habitat use and sexual segregation in the Galapagos sea lion (Zalophus californianus wollebaeki). Behav Ecol Sociobiol 59:293-302

Zieman JC, Iverson RL, Ogden JC (1984) Herbivory effects on Thalassia testudinum leaf growth and nitrogen content. Mar Ecol Prog Ser 15:151-158 


\section{Tables}

Table 1. Results for the General Linear Model relating green turtle encounters during 28 snorkelling censuses with time of day and depth ( $n=700$ encountered turtles).

\begin{tabular}{lcccccccccc}
\hline & \multicolumn{3}{c}{$\begin{array}{l}\text { Green turtle } \\
\text { population }\end{array}$} & \multicolumn{3}{c}{ Large turtles } & \multicolumn{3}{c}{ Small turtles } \\
\hline & $\mathrm{df}$ & $F$ & $\mathrm{p}$ & $\mathrm{df}$ & $F$ & $\mathrm{p}$ & $\mathrm{df}$ & $F$ & $\mathrm{p}$ \\
Time & 5 & 1.359 & 0.275 & 5 & 1.069 & 0.402 & 5 & 0.950 & 0.467 \\
Depth & 3 & 0.560 & 0.646 & 3 & 0.431 & 0.732 & 3 & 0.732 & 0.543 \\
Time x Depth & 15 & 0.853 & 0.619 & 15 & 1.111 & 0.424 & 15 & 0.347 & 0.975 \\
\hline
\end{tabular}

Electronic Supplementary material published as Appendices:

Appendix 1 Substrate type, leaf density, and leaf biomass for 24 randomly selected quadrats of $20 \mathrm{~cm} \times 20 \mathrm{~cm}$ (see Fig. 1) of the seagrass meadow at N'Gouja, Mayotte, 2005.

Appendix 2 Phytoecological table of the seagrass meadow at N'Gouja (Mayotte, 2005) based on four transects and 23 transect stations (see Fig. 1). 


\section{Figures}

Fig. 1 Map of the study site of N'Gouja Bay Mayotte Island, South Western Indian Ocean (SWIO). The seagrass meadow associated to shallow waters area is delimited by the white line, corresponding to a total surface area of $\sim 40$ ha. The present study occurred in a 13 ha area highlighted in white. Within the study site, (a) 24 random quadrats (identified by associated numbers) were sampled to investigate substrate and seagrass distribution, including 10 quadrats that were photographed (underlined numbers, see methods); (b) Four transects represented by the solid arrows (A, B, C, D) were used for the phytosociological surveys (the 23 transect stations along these transects are not indicated); (c) 23 snorkelling turtle censuses were performed following the same track (indicated by the dotted black line). Insert: (a) Geographic position of Mayotte in the SWIO; (b) Geographic position of N'Gouja in the south of Mayotte as indicated by the circle.

Fig. 2 Graphic representation of the Factorial Correspondence Analysis (FCA) conducted for 23 transect stations (filled triangles; Appendix 2) and 7 seagrass species/morphs* at N'Gouja Bay, Mayotte Island, in 2005. FCA reveals a Guttman effect (parabolic curve) indicating that most of the data inertia was associated with the first axis, being associated with distance to shore. FCA reveals the existence of four groups, referred as seagrass communities (C1, C2, $\mathrm{C} 3$ and C4) characterised by one or two seagrass species/morphs and distributed along the depth gradient (see Fig. 3). ${ }^{*} H$. ovalis, $H$. uninervis $T 1, H$. uninervis $T 2, S$. isoetifolium, $C$. rotundata, C. serrulata, T. hemprichii.

Fig. 3 Top: Distribution of seagrass communities and green turtles at N'Gouja Bay, Mayotte Island, in 2005. Seagrass communities (C1, C2, C3 and C4, see Fig. 2) were distributed along the depth gradient with $\mathrm{C} 1$ being closest to shore and $\mathrm{C} 4$ being the most seaward. Each community was dominated by one or two seagrass species/656 morphs, namely Halodule uninervis T1 (C1), Halodule uninervis T2 (C2), Halodule uninervis T2 and Syringodium isoetifolium (C3), and Syringodium isoetifolium (C4). Bottom: Proportion of each community surface area relative to the meadow total surface area (13 ha), and associated proportions of small and large green turtles encountered during five snorkelling censuses: Signs (-) and (+) indicate if green turtles occurred significantly (Neu et al. test) less or more respectively on a given seagrass communities once community surface area was taken into account. 


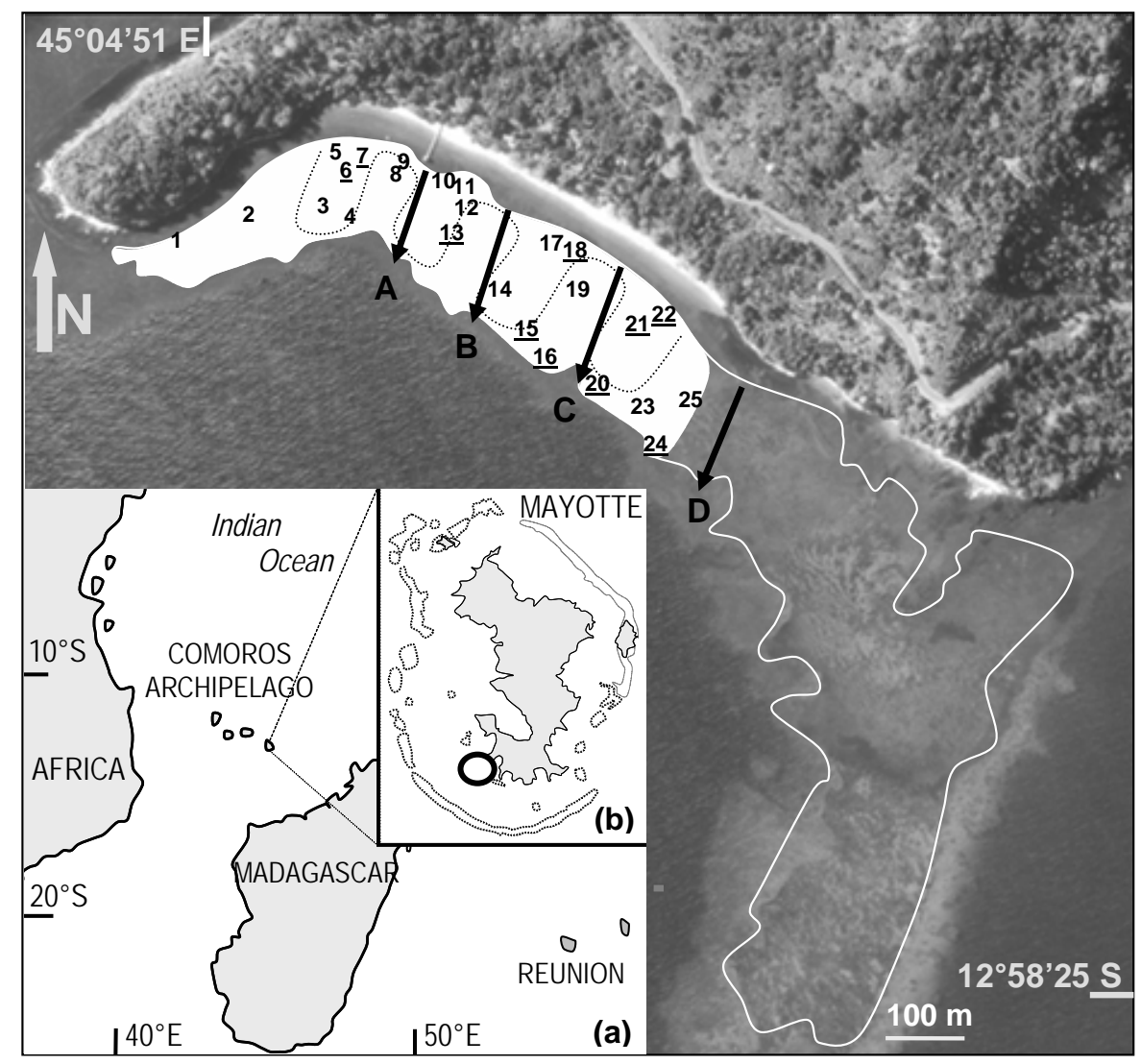

Fig. 1

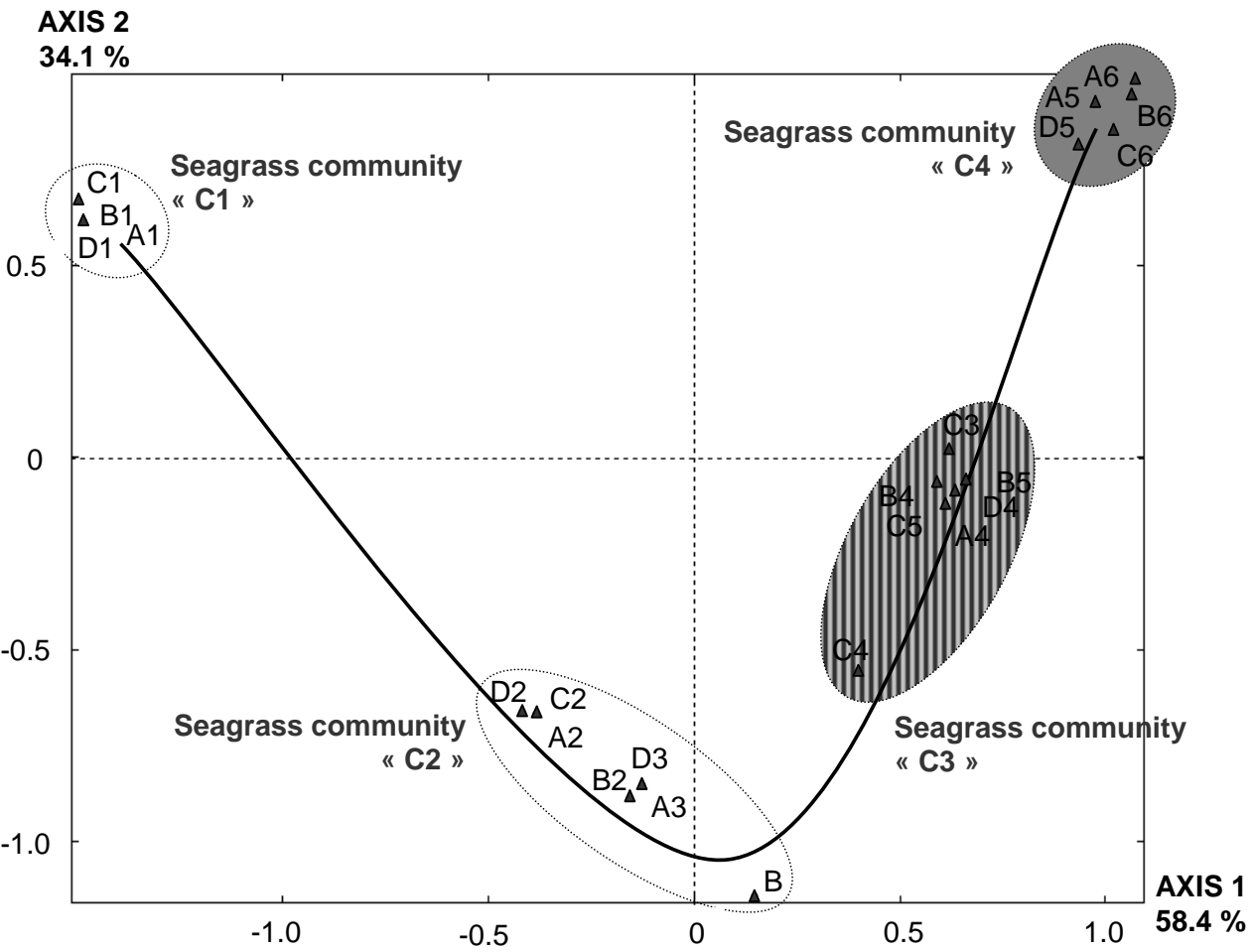

Fig. 2 


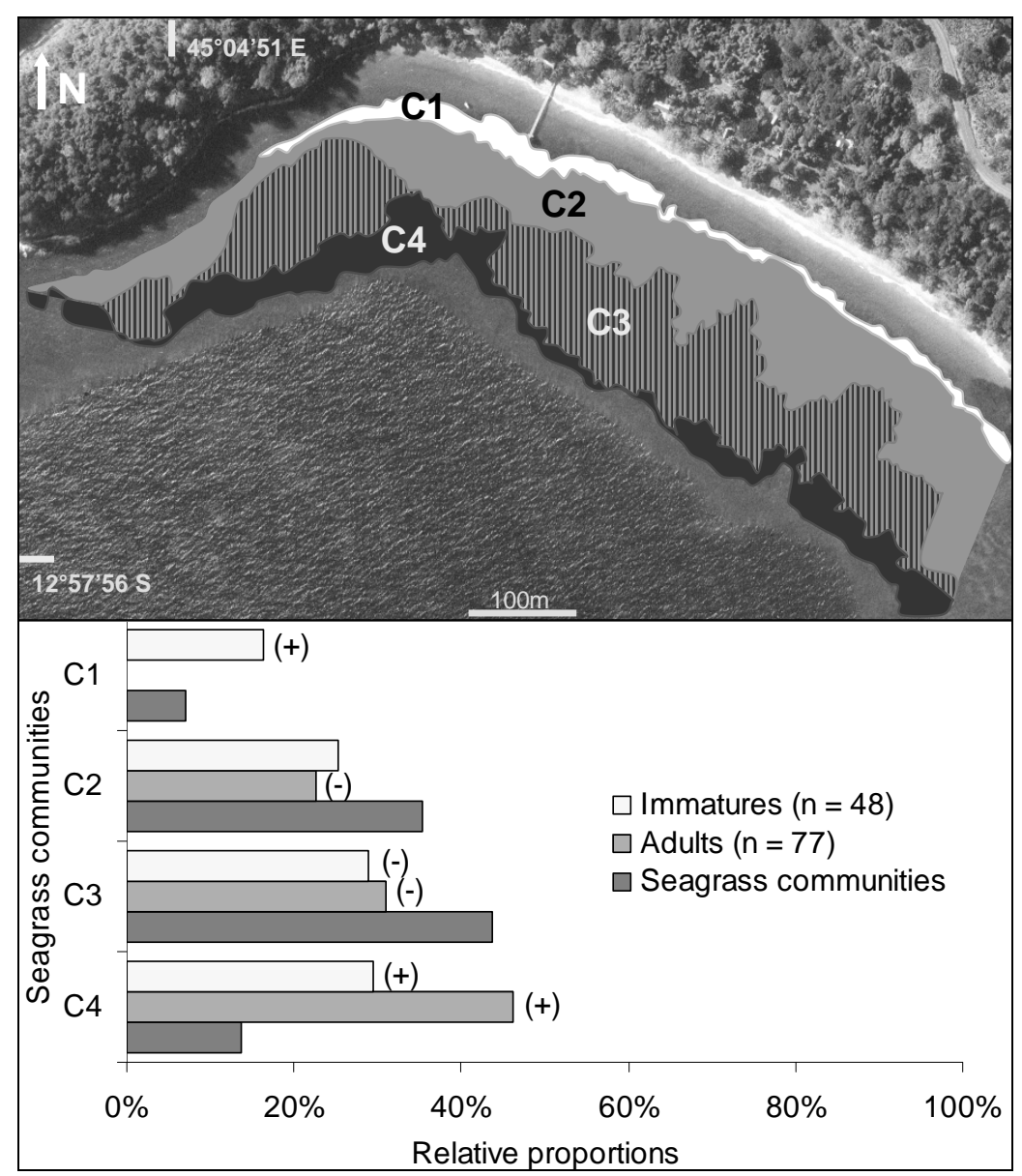

Fig. 3 